\title{
WATERMARKING PADA CITRA DIGITAL MENGGUNAKAN KOMBINASI PIXEL VALUE INDICATOR DAN METODE MOST SIGNIFICANT BIT
}

\author{
Posma Lumbanraja \\ Program Studi Pendidikan Teknologi Informasi \\ Universitas Methodist Indonesia \\ lumbanrajaposma@gmail.com
}

\begin{abstract}
One way to protect the copyright and authenticity of a digital image is to affix a watermark in the form of writing or a sign on the image. If the affixed watermark is visible, then its presence can interfere with the appearance of the image and it is possible that the watermark will be cut, discarded or cropped by parties who are not entitled to do so.

In this paper, an application is designed to affix a watermark in the form of an invisible message, or an invisible watermark by using a combination of pixel value indicator and the Most Significant Bit (MSB) method on the image, so that it is not detected visually and the visual appearance of the image is not disturbed. The message is scrambled using a key, then the scrambled bits are hidden in the 5th bit MSB and the 6th bit of the green channel or blue channel, depending on the number of bits 1 owned by the red channel which serves as an indicator. The process of hiding the watermark is carried out in the middle area of the image, so it is difficult to cut to remove it. Applications designed can be used to affix an invisible watermark in the form of messages that are not easily removed on digital images, so that they can protect the copyright of a digital image.
\end{abstract}

Keywords: Watermarking, Pixel Value Indicator, MSB

\section{PENDAHULUAN}

Penambahan suatu label pada citra digital sering dilakukan oleh pemiliknya untuk berbagai tujuan. Penambahan label tersebut dikenal dengan watermarking. Yang menjadi permasalahan adalah watermark yang ditambahkan pada citra secara konvensional adalah watermark yang terlihat (visible watermark), sehingga watermark tersebut dapat dihilangkan oleh pihak lain. Sebagai contoh, penambahan watermark pada bagian atas atau bagian bawah citra menghadapi kemungkinan watermark dapat dipotong dan dihapus oleh pihak lain tanpa persetujuan pemiliknya. Kemudian apabila watermark semi transparan ditambahkan pada bagian tengah citra tentu akan mengganggu pengamatan visual terhadap citra. Untuk mengatasi masalah ini, dapat ditamhahkan invisible watermark atau watermark yang tak terlihat secara kasat mata pada citra digital, sehingga dapat disisipkan informasi pada citra digital sesuai dengan yang diinginkan oleh pemilik citra. Salah satu metode watermarking yang sering digunakan adalah metode Least Significant Bit ( $L S B)$, yaitu dengan menambahkan bit watermark pada bit terakhir piksel, sehingga perubahan warna yang diakibatkan sangat kecil dan tidak dapat dideteksi secara kasat mata. Namun metode ini sudah sangat umum dan para hacker sering dengan mudah menyerang dan mengekstraksi data, sehingga perlu dicari solusi untuk mengatasinya. Sebagai suatu langkah solusi, pada penelitian ini digunakan kombinasi Pixel Value Indicator dan metode Most Significant Bit (MSB) untuk menyisipkan pesan watermark pada citra. Channel warna merah akan digunakan sebagai indikator untuk menyembunyikan data rahasia pada $M S B$ bit ke-5 dan bit ke-6 dari channel warna hijau atau channel warna biru. Agar lebih aman, maka penyisipan watermark akan disertai dengan penggunaan kunci yang berfungsi sebagai password untuk mengekstrak watermark pada citra. Apabila kunci yang digunakan untuk ekstraksi, tidak sesuai, maka watermark tidak dapat diekstraksi. Selain itu, penggunaan kunci, penggunaan channel warna merah sebagai indikator, dan MSB bit ke-5 dan 6 channel warna hijau dan biru sebagai tempat penyimpanan data (watermark) merupakan skema baru dan akan meningkatkan keamanan watermark. Berdasarkan uraian di atas, maka dalam tulisan ini dibahas bagaimana proses untuk menyembunyikan watermark pada citra digital menggunakan kombinasi pixel value indicator dan metode $M S B$, yang diimplementasikan pada citra *.jpg, *.bmp dan *.png. hingga 999 karakter, password hingga 20 karakter, dapat menampilkan proses perhitungan yang singkat. Hasil akhir dari penelitian ini dapat digunakan untuk berbagai kepentingan, misalnya untuk menjamin keaslian citra, melindungi hak cipta, dan menghindari penyalah gunaan maupun pelanggaran hukum.

\section{KERANGKA TEORI Watermarking}

Watermarking dapat dipandang sebagai suatu proses penyisipan sebuah data rahasia (watermark) terhadap sebuah gambar atau dokumen, yang berkembang hingga media digital atau disebut dengan Digital Watermarking 
yang dapat dijalankan pada berbagai media digital, seperti citra digital, suara dan video. Secara umum, watermarking adalah proses penyisipan citra digital dengan pesan atau watermark, seperti terlihat pada gambar 1.

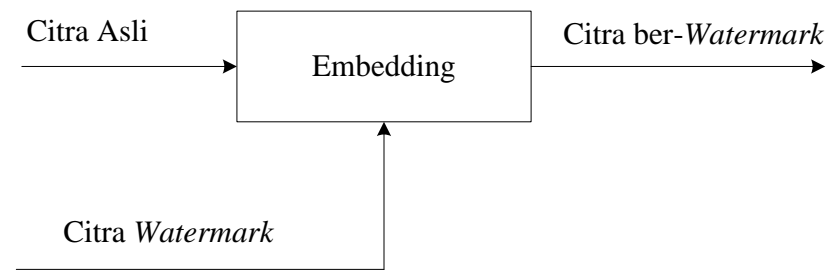

Gambar 1. Skema Watermarking

watermark yang disisipkan dalam citra digital haruslah imperceptible atau tidak terdeteksi oleh sistem penglihatan manusia (Human Visual System) atau sistem pendengaran manusia (Human Auditory System).

\section{Metode Least Significant Bit (LSB)}

Dalam metode ini, informasi disembunyikan dengan cara menyisipkannya pada bit rendah atau bit yang paling kanan $(L S B)$ data pixel yang menyusun file tersebut. Untuk berkas bitmap 24 bit, setiap pixel (titik) pada gambar yang terdiri dari susunan tiga warna merah, hijau dan biru (RGB) masing-masing disusun oleh bilangan 8 bit (1 byte) dari 0 sampai 255 atau dengan format biner 00000000 sampai 11111111. Dengan demikian, pada setiap pixel berkas bitmap 24 bit dapat disisipkan 3 bit data. Algorima pada metode LSB lebih cepat dan lebih mudah. Misalkan, sebuah karakter " $f$ " (kode ascii $=$ 131) akan disisipkan ke dalam suatu citra grayscale 8 bit yang berukuran $10 \times 10$ piksel, seperti terlihat pada gambar 2 berikut.

Citra grayscale 8 bit, $10 \times 10$ piksel

\begin{tabular}{|l|l|l|l|l|l|l|l|l|l|}
\hline 1 & 6 & 5 & 3 & 7 & 4 & 7 & 4 & 1 & 0 \\
\hline 3 & 5 & 3 & 5 & 5 & 5 & 5 & 7 & 7 & 0 \\
\hline 0 & 0 & 0 & 2 & 2 & 6 & 6 & 6 & 6 & 6 \\
\hline 5 & 5 & 4 & 4 & 4 & 4 & 4 & 4 & 7 & 3 \\
\hline 2 & 2 & 0 & 0 & 0 & 0 & 1 & 1 & 1 & 1 \\
\hline 7 & 5 & 5 & 5 & 7 & 7 & 7 & 6 & 3 & 3 \\
\hline 3 & 3 & 3 & 3 & 3 & 3 & 3 & 3 & 7 & 5 \\
\hline 5 & 5 & 5 & 5 & 5 & 5 & 5 & 5 & 2 & 3 \\
\hline 0 & 0 & 0 & 0 & 0 & 0 & 4 & 4 & 4 & 4 \\
\hline 3 & 3 & 3 & 3 & 3 & 1 & 1 & 1 & 6 & 2 \\
\hline
\end{tabular}

Gambar 2. Citra Grayscale 8 bit dengan ukuran 10 x 10 piksel

Langkah pertama adalah mengubah kedua data tersebut (huruf dan citra) menjadi nilai biner (gambar 2.3). Nilai biner untuk huruf " $f$ " adalah 10000011. Oleh karena jumlah digit biner huruf hanya 8 bit, maka jumlah piksel citra yang dibutuhkan untuk menyembunyikan huruf tersebut cukup 8 piksel saja.

\begin{tabular}{|c|c|c|c|c|c|c|c|c|c|c|c|}
\hline \multicolumn{10}{|c|}{8 piksel pertama dirmbel } & \multirow{3}{*}{$\begin{array}{l}\text { Pkssel Chra } \\
1=00000001\end{array}$} & \multirow{3}{*}{$\begin{array}{l}\text { Haruf "ff } \\
\text { (asc=151) }\end{array}$} \\
\hline 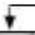 & & & & & & & 7 & & & & \\
\hline 1 & 6 & 5 & 3 & 7 & 4 & 7 & 4 & 1 & 0 & & \\
\hline 3 & 5 & 3 & 5 & 5 & 5 & 5 & 7 & 7 & 0 & $6=00000110$ & 0 \\
\hline 0 & 0 & 0 & 2 & 2 & 6 & 6 & 6 & 6 & 6 & $5=00000101$ & 0 \\
\hline 5 & 5 & 4 & 4 & 4 & 4 & 4 & 4 & 7 & 3 & $\hat{z}=00000011$ & 0 \\
\hline 2 & 2 & 0 & 0 & 0 & 0 & 1 & 1 & 1 & 1 & $7=00000111$ & 0 \\
\hline 7 & 5 & 5 & 5 & 7 & 7 & 7 & 6 & 3 & 3 & $t=00000100$ & 0 \\
\hline 3 & 3 & 3 & 3 & 3 & 3 & 3 & 3 & 7 & 5 & $7=00000111$ & 1 \\
\hline 5 & 5 & 5 & 5 & 5 & 5 & 5 & 5 & 2 & 3 & $4=00000100$ & 1 \\
\hline 0 & 0 & 0 & 0 & 0 & 0 & 4 & 4 & 4 & 4 & & \\
\hline 3 & 3 & 3 & 3 & 3 & 1 & 1 & 1 & 6 & 2 & & \\
\hline
\end{tabular}

Langkah kedua adalah mengganti bit terakhir (Least Significant Bit / LSB) dari piksel citra dengan bit-bit dari huruf, seperti terlihat pada gambar 4 berikut.

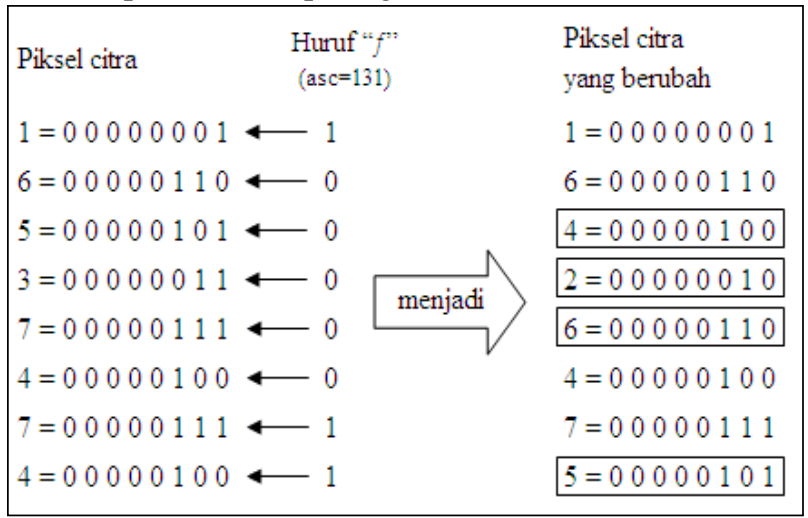

Gambar 4. Proses Penyisipan dengan Metode $L S B$

Setelah penyisipan, bit-bit piksel citra yang mengalami perubahan hanya 4 piksel saja, seperti terlihat pada gambar 5 berikut.

4 piksel yang berubah
\begin{tabular}{|c|c|c|c|c|c|c|c|c|c|}
\hline 1 & 6 & 4 & 2 & 6 & 4 & 7 & 5 & 1 & 0 \\
\hline 3 & 5 & 3 & 5 & 5 & 5 & 5 & 7 & 7 & 0 \\
\hline 0 & 0 & 0 & 2 & 2 & 6 & 6 & 6 & 6 & 6 \\
\hline 5 & 5 & 4 & 4 & 4 & 4 & 4 & 4 & 7 & 3 \\
\hline 2 & 2 & 0 & 0 & 0 & 0 & 1 & 1 & 1 & 1 \\
\hline 7 & 5 & 5 & 5 & 7 & 7 & 7 & 6 & 3 & 3 \\
\hline 3 & 3 & 3 & 3 & 3 & 3 & 3 & 3 & 7 & 5 \\
\hline 5 & 5 & 5 & 5 & 5 & 5 & 5 & 5 & 2 & 3 \\
\hline 0 & 0 & 0 & 0 & 0 & 0 & 4 & 4 & 4 & 4 \\
\hline 3 & 3 & 3 & 3 & 3 & 1 & 1 & 1 & 6 & 2 \\
\hline
\end{tabular}

Gambar 5. Hasil Penyisipan dengan Metode $L S B$ 
Pada gambar 5, terlihat bahwa piksel yang mengalami perubahan hanya sebesar 1 intensitas saja. Oleh karena itu, secara kasat mata, hal ini tidak terlalu berpengaruh, dan tidak semua piksel mengalami perubahan.

\section{Kombinasi Pixel Value Indicator dan Most Significant Bit (MSB)}

Kebalikan dari $L S B$ adalah Most Significant Bit (MSB). Pada metode $M S B$, bit-bit pesan disembunyikan pada bitbit paling depan dari piksel citra. Namun, kelemahan dari metode $M S B$ adalah warna citra berubah drastis, seperti terlihat pada gambar 6 berikut.

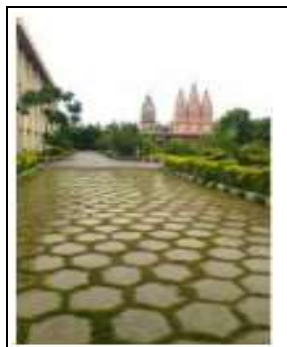

Citra Asli

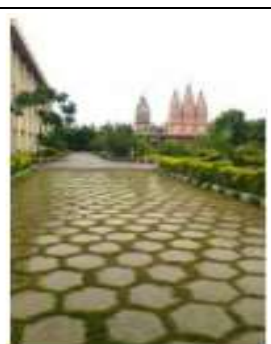

Citra Hasil LSB

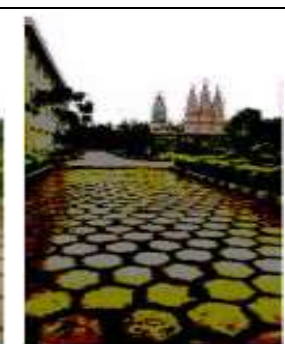

Citra Hasil MSB
Gambar 6. Watermarking LSB dan MSB

Pada gambar 2.6 terlihat bahwa metode $L S B$ tidak terlihat mengubah warna citra, bila dibandingkan dengan metode $M S B$. Namun perlu dilakukan modifikasi dengan menggunakan teknik pixel indicator untuk menyembunyikan watermark pada bit MSB citra. Channel warna merah akan digunakan sebagai indikator untuk menyembunyikan data rahasia pada $M S B$ bit ke-5 dan bit ke-6 dari channel warna hijau atau channel warna biru disertai dengan penggunaan kunci yang berfungsi sebagai password untuk mengekstrak watermark dari citra, sehingga watermark lebih sulit diekstraksi. Penggunaan kunci, penggunaan channel warna merah sebagai indikator, dan $M S B$ bit ke-5 dan 6 channel warna hijau dan biru sebagai tempat penyimpanan data (watermark) merupakan suatu tindakan yang akan meningkatkan keamanan watermark. Flowchart dari penyisipan bit pesan pada citra digital dapat dilihat pada gambar 7 .

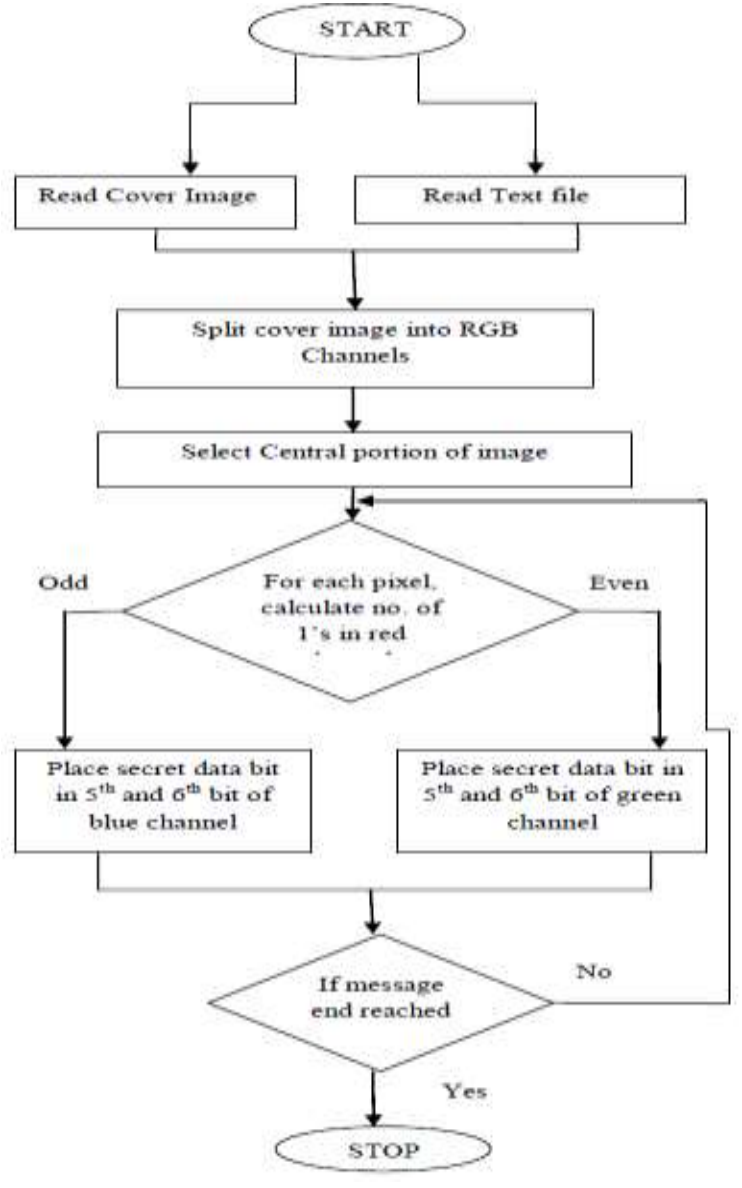

Gambar 7. Proses Penyembunyian Pesan pada Citra

Berikut adalah algoritma yang digunakan untuk mengekstraksi pesan dari citra:

1. Pilih gambar yang telah memiliki watermark.

2. Temukan bagian tengah citra.

3. Bagi citra menjadi 3 channel, yaitu Red, Green, dan Blue.

4. Untuk setiap piksel 24 bit, lakukan langkah no. 5 dan 6.

5. Jika jumlah bit 1 pada channel Red adalah genap, maka ekstraksi bit pesan dari posisi bit ke-5 dan bit ke-6 dari channel Green.

6. Jika jumlah bit 1 pada channel Red adalah ganjil, maka ekstraksi bit pesan dari posisi bit ke-5 dan bit ke-6 dari channel Blue.

7. Output adalah pesan watermark.

\section{PEMBAHASAN}

Proses pembahasan mencakup proses penentuan daerah penyembunyian watermark, proses penyembunyian watermark dengan kombinasi Pixel Value Indicator dan metode Most Significant Bit (MSB), proses ekstraksi watermark, dan pemodelan sistem. 
a. Penentuan Daerah Penyembunyian Watermark

Pada penelitian ini, watermark disembunyikan di area tengah citra, dengan pertimbangan bahwa area tengah merupakan inti atau sentral dari citra dan jauh lebih aman dari proses cropping

Dengan menggunakan kombinasi pixel value indicator dan metode $M S B$, satu piksel citra dapat menampung 2 bit biner watermark pada channel warna biru atau channel warna hijau, bergantung pada indikator channel warna merah. Batas watermark yang dapat disembunyikan pada citra dibatasi sebanyak 999 karakter, bila diubah ke bit biner adalah sebesar 999 × 8 atau sama dengan 7992 bit biner. Apabila 7992 bit dibagi dengan 2 bit, maka dibutuhkan 3996 piksel untuk menampung seluruh karakter watermark. Untuk menentukan luas area piksel yang menampung 3996 piksel, maka dilakukan perhitungan $\sqrt{3996}$ atau didapat angka 63.21 atau dibulatkan menjadi 64. Dengan demikian, dibutuhkan area seluas 64 x 64 piksel di area tengah citra untuk menampung karakter watermark. Sebagai contoh, digunakan citra berukuran 640 x 480 piksel, seperti terlihat pada gambar 8 .

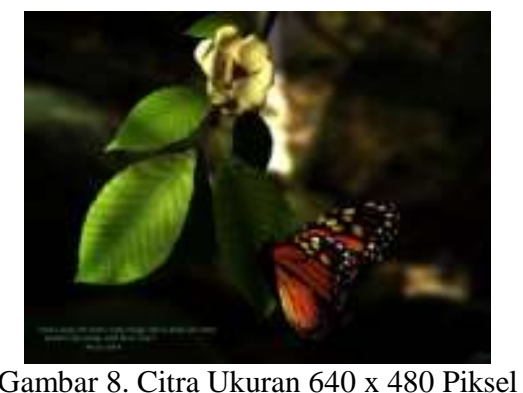

Dengan ukuran 640 x 480 piksel, maka perhitungan posisi awal penyembunyian watermark dimulai pada posisi:
Ukuran citra : $\quad$ Lebar $=640 \quad$ Tinggi $=$

480

Piksel di tengah citra $\quad: X=640 / 2=320$

$\mathrm{Y}=480 / 2=240$

Ukuran area watermark $: 64 \times 64$ piksel

Posisi tengah area citra $: \mathrm{X}=($ Lebar citra $/ 2)-$

(Uk. area watermark/2)

$\mathrm{Y}=($ Tinggi citra $/ 2)-(\mathrm{Uk}$

area watermark/2)

Posisi tengah area citra $\quad: X=320-(64 / 2)=288$

$\mathrm{Y}=240-(64 / 2)=208$

Dengan demikian untuk citra berukuran $640 \mathrm{x}$ 480 piksel, area penyembunyian data watermark akan dimulai pada posisi piksel $\mathrm{X}=288$ dan $\mathrm{Y}=208$, seperti terlihat pada gambar 9 .

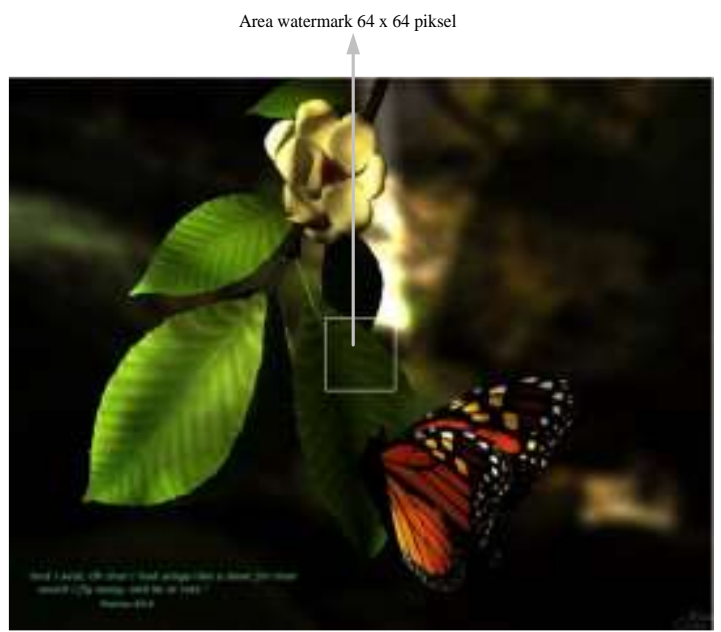

Gambar 9. Area Penyembunyian Watermark

\section{b. Penyembunyian Watermark}

Berikut adalah algoritma yang digunakan untuk menyembunyikan watermark pada citra dengan kombinasi pixel value indicator dan metode MSB:

1. Input citra untuk diberikan watermark.

2. Input kunci dan watermark.

3. Pilih bagian tengah citra

4. Piksel ke-1 dan piksel ke-2 pada area tengah citra dimasukkan penanda dimulainya watermark, yaitu: "RIDOCG" (setelah di-XOR dengan kunci), sedangkan piksel ke-3 dimasukkan jumlah karakter watermark.

5. Watermark diproses dengan fungsi $X O R$ dengan kunci rahasia.

6. Untuk setiap piksel 24 bit, lakukan langkah berikut:

a. Jika jumlah bit 1 pada channel Red adalah genap, maka tempatkan dua bit watermark pada posisi bit ke-5 dan bit ke-6 dari channel Green .

b. Jika jumlah bit 1 pada channel Red adalah ganjil, maka tempatkan dua bit watermark pada posisi bit ke-5 dan bit ke-6 dari channel Blue.

7. Output adalah citra yang telah disisipi pesan watermark.

\section{c. $\quad$ Ekstraksi Watermark}

Berikut adalah algoritma yang digunakan untuk mengekstraksi watermark dari citra dengan kombinasi pixel value indicator dan metode $M S B$ :

1. Input citra hasil watermark.

2. Input kunci.

3. Cari penanda awal pada citra sebagai posisi awal area watermark.

4. Ambil besarnya karakter watermark yang akan diekstraksi pada penanda.

5. Untuk setiap piksel 24 bit, lakukan langkah berikut:

a. Jika jumlah bit 1 pada channel Red adalah genap, maka ekstraksi dua bit watermark pada posisi bit ke-5 dan bit ke-6 dari channel Green . 
b. Jika jumlah bit 1 pada channel Red adalah ganjil, maka ekstraksi dua bit watermark pada posisi bit ke-5 dan bit ke-6 dari channel Blue.

6. Bit ekstraksi diproses dengan fungsi XOR dengan kunci rahasia.

7. Output hasil XOR adalah karakter watermark.

\section{Perancangan Sistem}

Aplikasi implementasi watermarking pada citra digital menggunakan kombinasi Pixel Value Indicator dan metode Most Significant Bit untuk proteksi hak cipta citra digital ini dirancang dengan menggunakan bahasa pemrograman Microsoft Visual Basic .Net 2008. Aplikasi mempunyai beberapa form, diantaranya adalah: Form Utama, Form Penyembunyian Watermark, Form Ekstraksi Watermark, Form Perbandingan Citra, dan Form About.

\section{Form Utama}

Pada form utama, terdapat toolbar untuk melakukan proses penyembunyian dan ekstraksi watermark. Rancangan form utama dapat dilihat pada gambar 10.

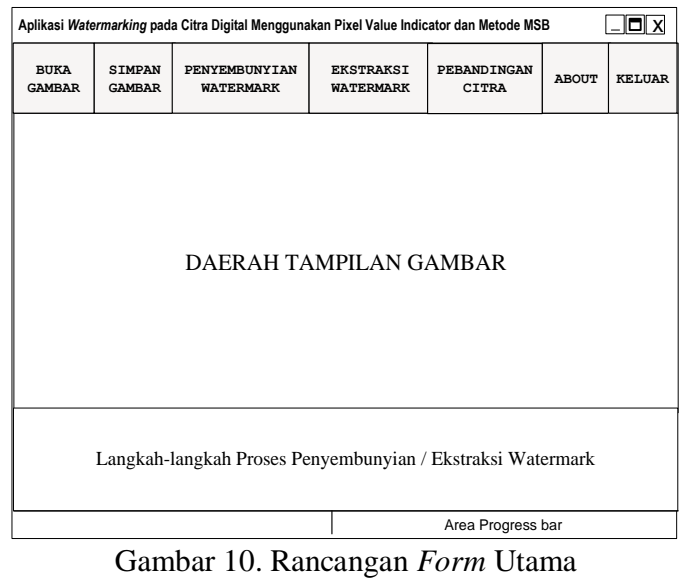

\section{Form Penyembunyian Watermark}

Pada form ini, aplikasi akan meminta input kunci dan input watermark, sesaat setelah pengguna mengklik tombol 'Penyembunyian Watermark' pada form Utama. Tujuannya adalah agar aplikasi dapat menyembunyikan watermark ke citra dengan menggunakan kunci. Rancangan form dapat dilihat pada gambar 11.

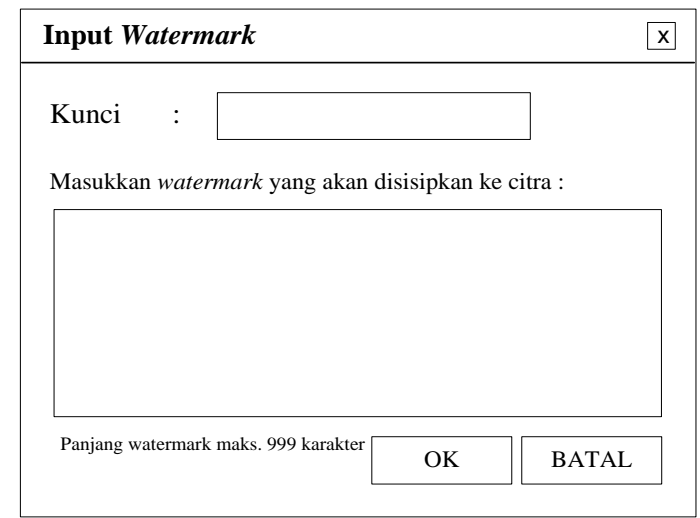

Gambar 11. Rancangan Form Penyembunyian Watermark

\section{Form Ekstraksi Watermark}

Form ini muncul setelah pengguna mengklik tombol 'Ekstraksi Watermark' dari form utama. Fungsi form ini adalah untuk memasukkan kunci dan menampilkan hasil ekstraksi watermark. Rancangan form dapat dilihat pada gambar 12.

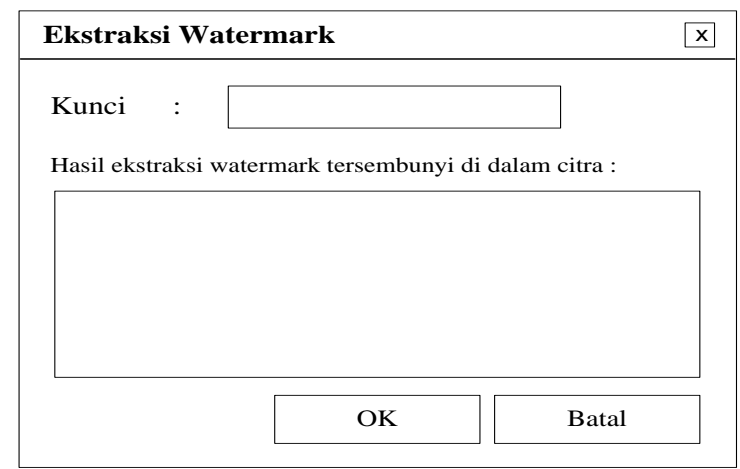

Gambar 12. Rancangan Form Ekstraksi Watermark

\section{Form Perbandingan}

Pada form ini, pengguna dapat membandingkan tampilan citra asli dan citra hasil watermark. Rancangan form dapat dilihat pada gambar 13 .

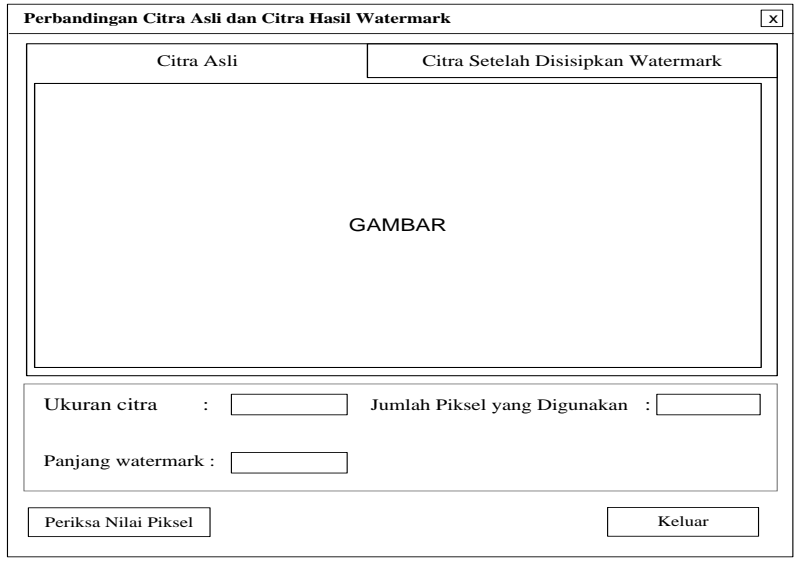

Gambar 13. Rancangan Form Perbandingan Citra 
IV. ALGORITMA DAN IMPLEMENTASI

Algoritma dari proses penyembunyian watermark pada citra dengan kombinasi pixel value indicator dan metode $M S B$ dapat digambarkan dalam bentuk flowchart, seperti terlihat pada gambar 15 .

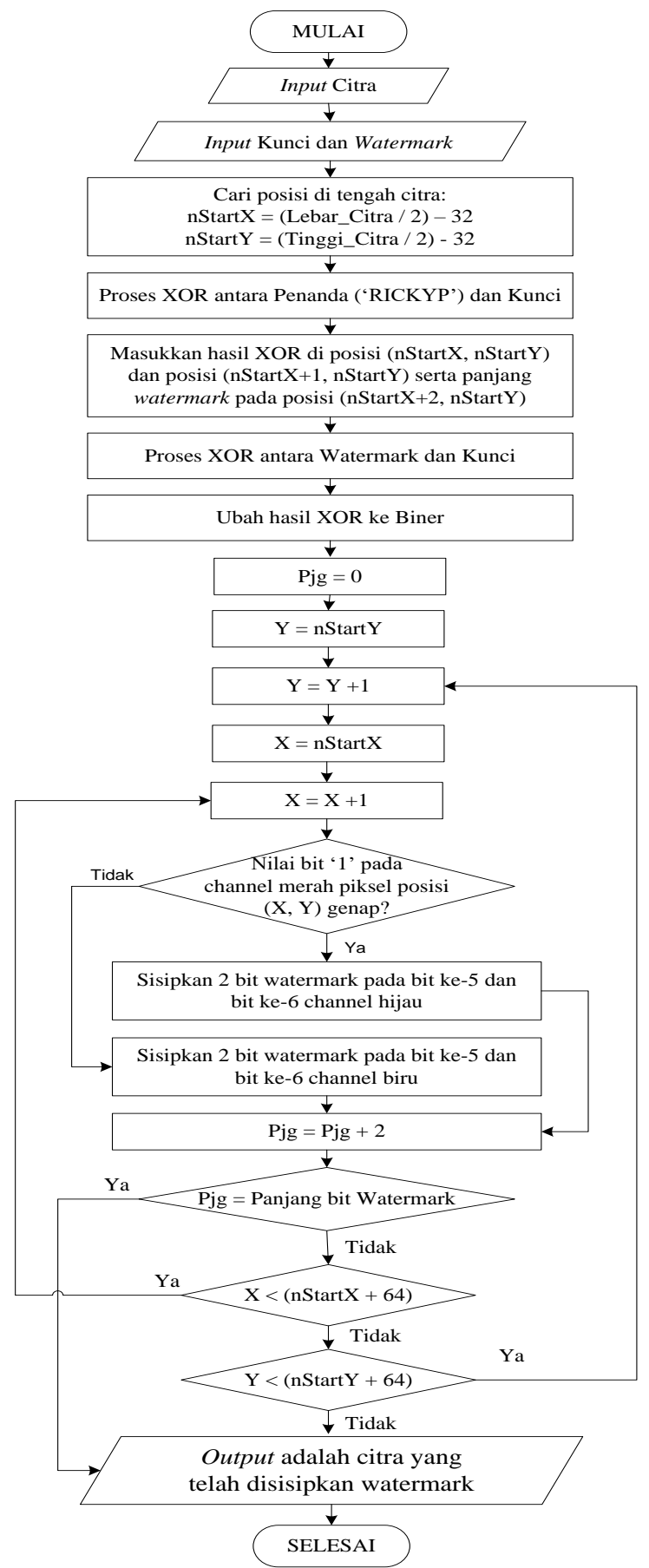

Gambar 15. Flowchart Algoritma Penyembunyian Watermark pada Citra

Proses ekstraksi watermark dengan kombinasi pixel value indicator dan metode MSB dapat dilihat pada flowchart, seperti terlihat pada gambar 16 .

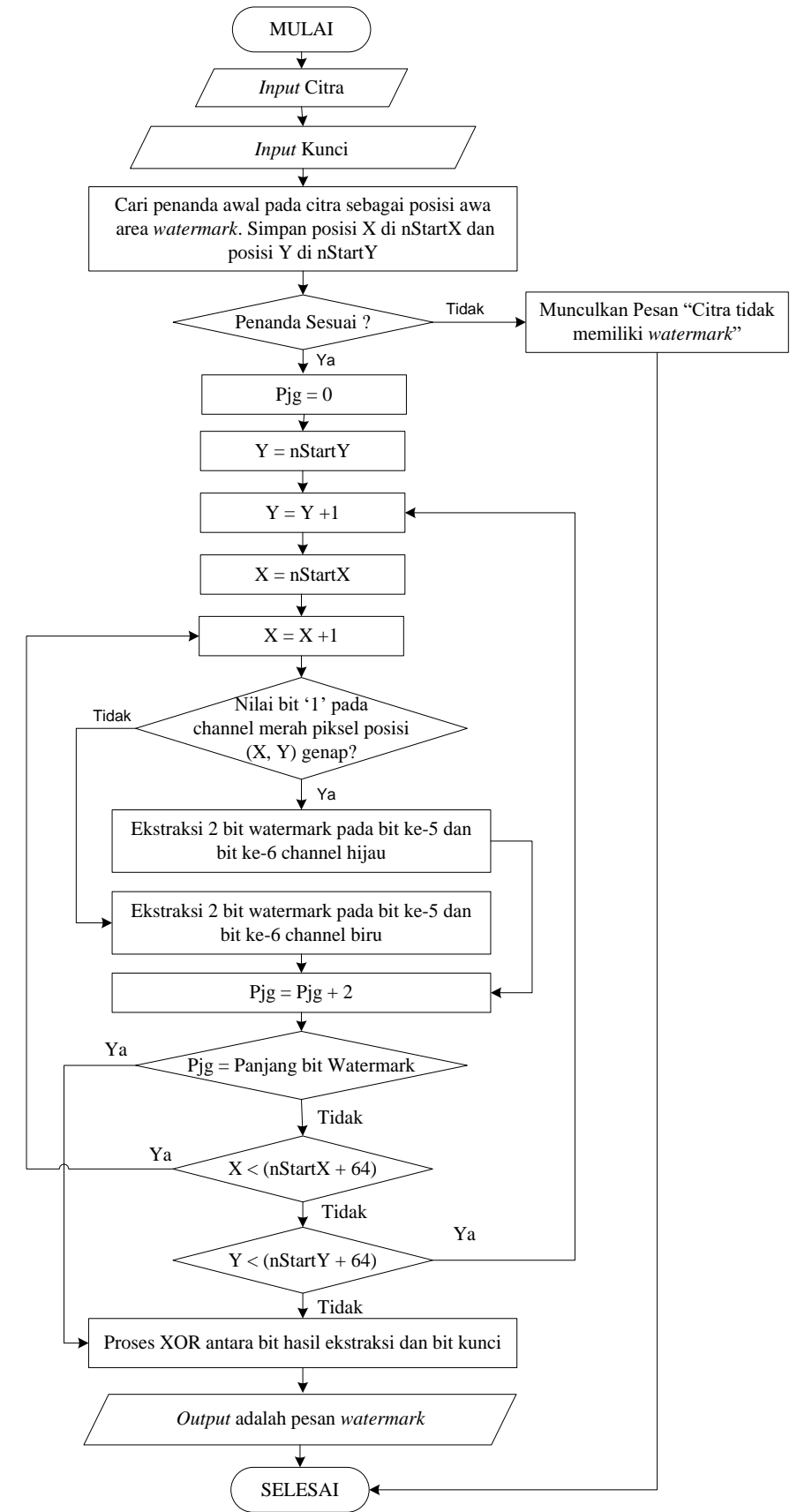

Gambar 16. Flowchart Algoritma Ekstraksi Watermark dari Citra

\section{Implementasi}

Berikut dijelaskan mengenai implementasi dari aplikasi watermarking pada citra digital menggunakan kombinasi Pixel Value Indicator dan metode Most Significant Bit untuk proteksi hak cipta citra digital. Form Utama akan muncul pada saat aplikasi dijalankan, seperti terlihat pada gambar 17. 


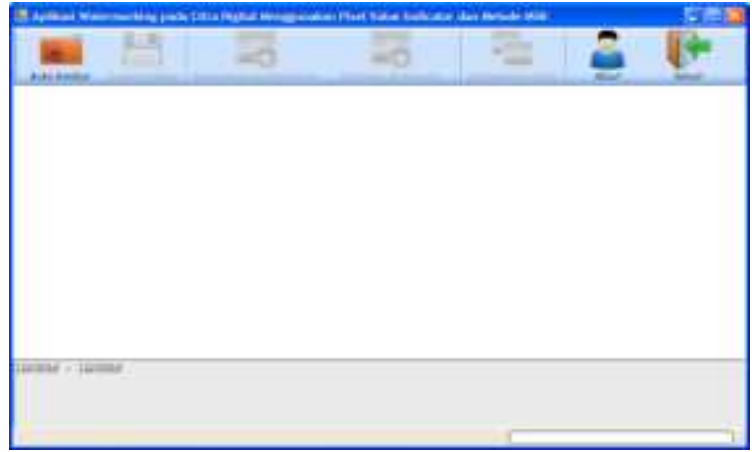

Gambar 17. Form Utama

Untuk membuka gambar, klik tombol "Buka Gambar" pada toolbar di bagian atas form utama. Kotak dialog Open File dari windows akan muncul seperti terlihat pada gambar 18.

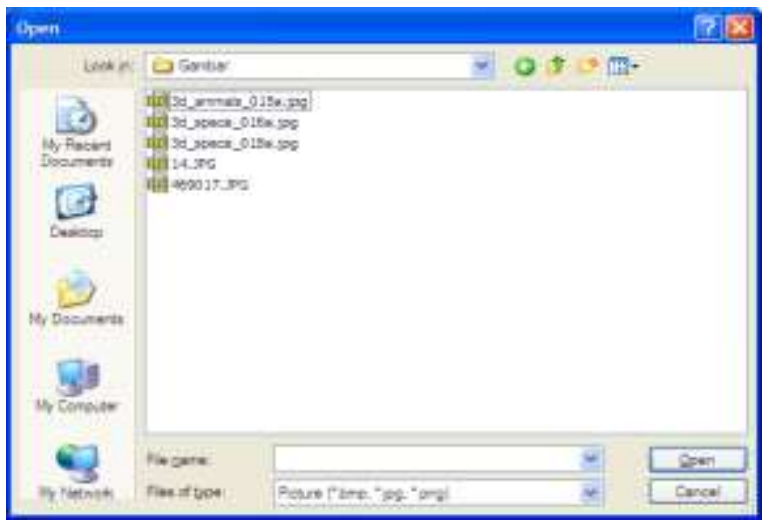

Gambar 18. Kotak Dialog Open File

Pilih salah satu gambar dan klik tombol "Open", dan file gambar akan di-load pada form utama, seperti terlihat pada gambar 19.

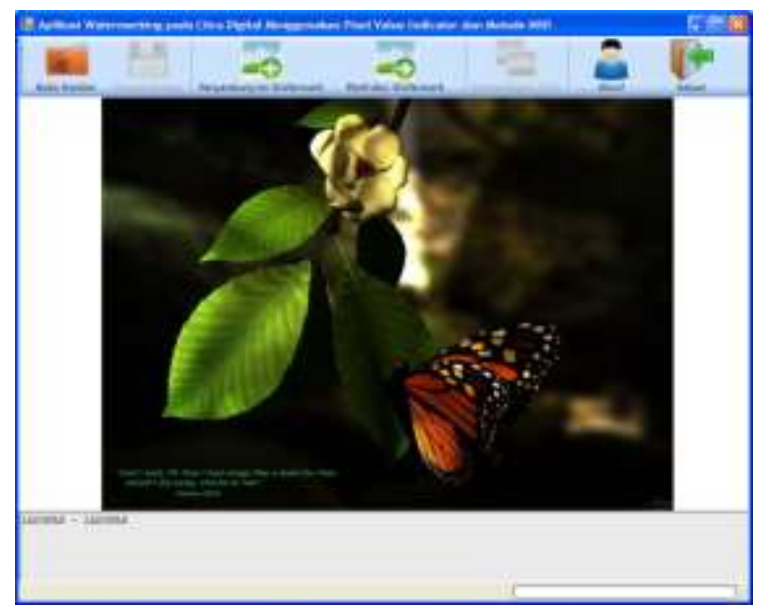

Gambar 19. Tampilan Gambar pada Form Utama

Untuk menyembunyikan watermark pada citra, tekan tombol "Penyembunyian Watermark" pada toolbar di bagian atas form utama, dan form penyembunyian watermark akan muncul seperti terlihat pada gambar 20 .

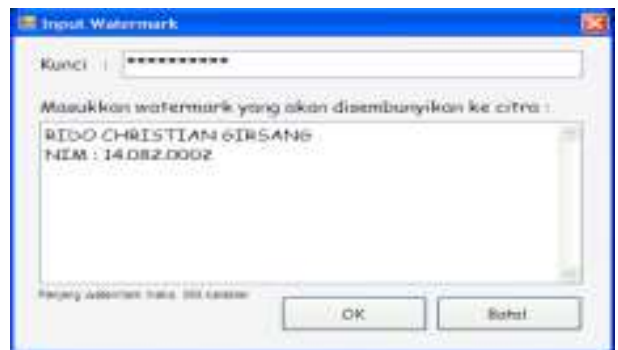

Gambar 20. Form Penyembunyian Watermark

Masukkan kunci atau password (sebagai contoh "kunci12345"), dan watermark yang akan disisipkan, lalu tekan tombol "OK" untuk memulai proses penyembunyian watermark ke citra digital, seperti terlihat pada gambar 21.

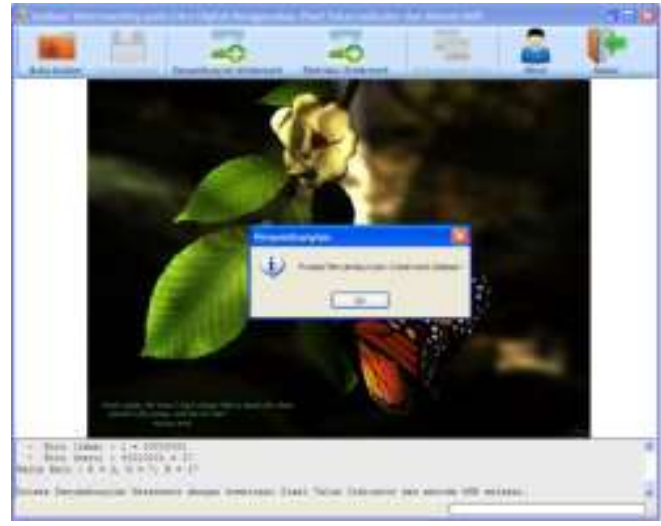

Gambar 21. Proses Penyembunyian Watermark

Untuk melakukan ekstraksi watermark dari citra, tekan tombol "Ekstraksi Watermark", dan proses ekstraksi akan berjalan, seperti terlihat pada gambar 22 .

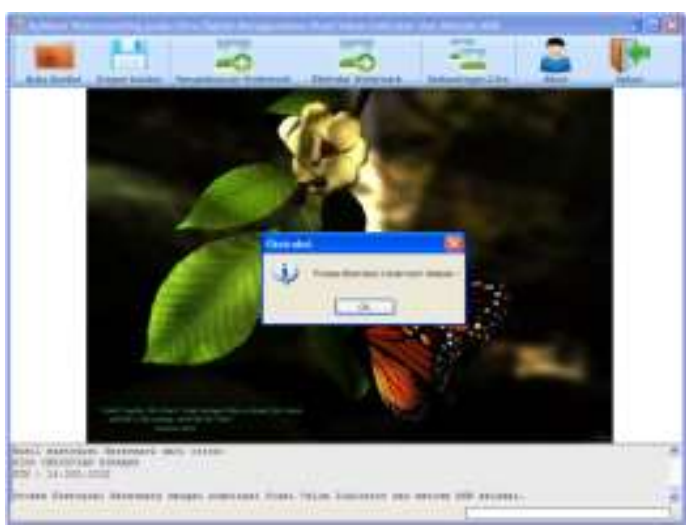

Gambar 22. Proses Ekstraksi Watermark

Dengan menggunakan kunci yang benar, maka watermark akan terekstraksi dengan benar pada form Ekstraksi Watermark, seperti terlihat di gambar 23. 


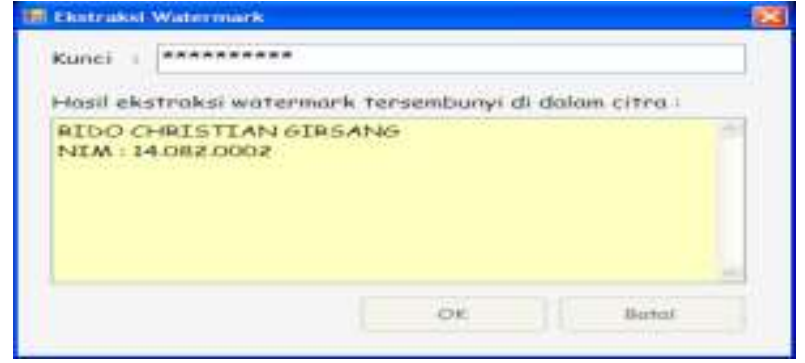

Gambar 23. Hasil Ekstraksi Watermark dengan Kunci Benar

Apabila proses ekstraksi watermark menggunakan kunci yang salah, maka watermark tidak dapat diekstraksi, seperti terlihat pada gambar 24 .

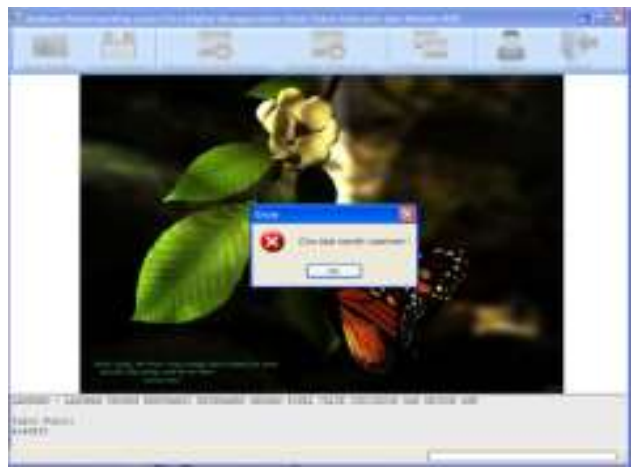

Gambar 24. Proses Ekstraksi Watermark Kunci yang Salah

Untuk melihat perbandingan antara citra asli dengan citra hasil watermark, maka tekan tombol "Perbandingan Citra", dan form perbandingan akan muncul seperti terlihat pada gambar 4.11. Form perbandingan berisi citra asli, citra setelah disisipkan watermark, ukuran citra, panjang watermark, dan jumlah piksel yang digunakan pada citra untuk menyembunyikan watermark. Apabila dibandingkan secara manual, citra hasil penyembunyian watermark terlihat sama dengan citra asli. Akan tetapi terdapat perbedaan nilai warna piksel yang tidak terlihat secara kasat mata. Untuk dapat melihat perbandingan nilai piksel antara citra asli dan citra hasil watermark, maka user dapat menekan tombol "Periksa Watermark" untuk memeriksa nilai warna piksel pada posisi piksel yang ditentukan.

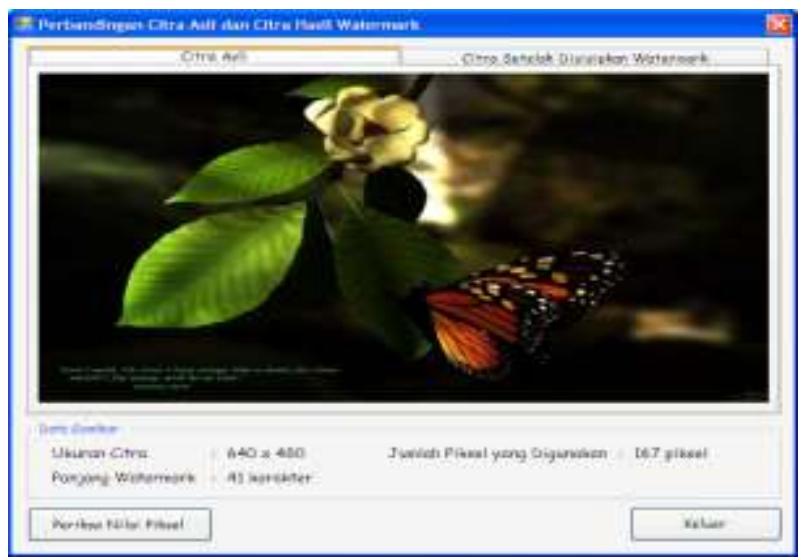

Gambar 25. Form Perbandingan Citra

\section{KESIMPULAN DAN SARAN}

\subsection{Kesimpulan}

Setelah menyelesaikan perancangan Aplikasi implementasi watermarking pada citra digital menggunakan kombinasi Pixel Value Indicator dan metode Most Significant Bit, beberapa hal yang dapat disimpulkan dari penelitian adalah sebagai berikut:

1. Aplikasi dapat digunakan untuk melindungi hak cipta sebuah citra dengan menyembunyikan watermark pada citra digital menggunakan kombinasi Pixel Value Indicator dan metode $M S B$, yaitu dengan menyembunyikan data rahasia pada $M S B$ bit ke-5 dan bit ke-6 dari channel warna hijau atau channel warna biru menggunakan channel warna merah sebagai indikator.

2. Aplikasi menggunakan kunci rahasia, sehingga apabila proses ekstraksi menggunakan kunci yang salah, maka watermark tidak dapat diekstraksi.

3. Citra hasil watermark terlihat sama dengan citra asli secara kasat mata, walaupun sebenarnya terdapat perbedaan nilai piksel.

4. Watermark disembunyikan pada bagian tengah dari citra, sehingga watermark tetap dapat diekstraksi walaupun citra dipotong (crop) pada bagian atas, bagian bawah, samping kiri atau samping kanan.

\section{Saran}

Untuk pengembangan aplikasi lebih lanjut di masa yang akan datang, beberapa hal yang dapat disarankan sebagai berikut:

1. Disarankan untuk menambahkan algoritma kompresi pada pesan watermark, sehingga dapat memperkecil ukuran pesan watermark yang akan disembunyikan.

2. Disarankan untuk mengembangkan aplikasi menjadi aplikasi steganografi yang dapat menyembunyikan file rahasia pada citra digital.

\section{DAFTAR PUSTAKA}

[1]. Anand, K, and Sharma, M, 2014, Data Security Using $L S B \&$ MSB Imange Steganography, Haryana, India : Swami Devi Dyal Institute of Engg \& Technology

[2]. Hakim, A.R, 2012, Analisa Perbandingan Water marking ImageMenggunakan Discrete Wavelet Transform, Universitas Indonesia, Depok

[3]. Hidayatullah, P , 2017, Pengolahan Citra Digital (Teory dan AplikasinNyata) Informatika, Bandung

[4]. Paradhipta, B.R,2015, Penerapan Teknik Watermarking Metode DWT pada Citra Digital, Universitas Sanata Dharma, Yogyakarta.

[5]. Sharma, A., 2017, A Secure SteganographyTechnique Using MSB, Kurukshetra University, India 